\title{
Growth Behavior of Wheat Cultivars under Different Irrigation Levels
}

\author{
Manoj Kumar Gora ${ }^{1 *}$, M.Z. Siddiqui ${ }^{1}$ and Shankar Lal Choudhary ${ }^{2}$ \\ ${ }^{1}$ Chandra Shekhar Azad University of Agriculture and Technology, Kanpur (U.P.), India \\ ${ }^{2}$ Sri Karan Narendra Agriculture University, Jobner, Jaipur, Rajasthan, India \\ *Corresponding author
}

\begin{tabular}{|c|c|}
\hline & A B S T R A C T \\
\hline & The present study was carried out at the student's instructional farm of Chandra \\
\hline Keywords & $\begin{array}{l}\text { Shekhar Azad University of Agriculture and Technology, Kanpur, (U.P.) during } \\
\text { rabi season of 2015-16. The experiment was conducted under split plot design }\end{array}$ \\
\hline $\begin{array}{l}\text { Irrigation, CRI, } \\
\text { Booting, Tillering, } \\
\text { Milking. }\end{array}$ & $\begin{array}{l}\text { with three replications, treatments comprising of two irrigation levels ( } \mathrm{I}_{1}-\mathrm{CRI} \text {, } \\
\text { Booting and Milking stages and } \mathrm{I}_{2}-\mathrm{CRI} \text {, Maximum Tillering, Booting and } \\
\text { Milking stages) in main plots, two varieties ( } \mathrm{K} 402 \text { and } \mathrm{K} 1006) \text { in sub-plots. }\end{array}$ \\
\hline Article Info & $\begin{array}{l}\text { Results of present study revealed that four irrigation CRI, Maximum Tillering, } \\
\text { Booting and Milking stages shown its superiority in plant height, fresh weight and }\end{array}$ \\
\hline $\begin{array}{l}\text { Accepted: } \\
\text { 04 July } 2017 \\
\text { Available Online: } \\
\text { 10 September } 2017\end{array}$ & $\begin{array}{l}\text { dry weight, total no of spike per meter length, Grain Weight per panicle, test } \\
\text { weight. It was also revealed from the data that four irrigation CRI, Maximum } \\
\text { Tillering, Booting and Milking stages shown its superiority in grain yield (51.464 }\end{array}$ \\
\hline & (Rs.77,642/ha) and B:C ratio $(1: 3.46)$. \\
\hline
\end{tabular}

\section{Introduction}

Wheat (Triticum aestivum L.) belonging to family poaceae is the single most important cereal crop, that has been considered as integral component of the food security system of several nations. It is important food crop of whole world.

It is consumed mostly in the form of bread as "Chapati". Wheat straw is used for feeding the cattle. Wheat contains more protein than other cereals and has relatively high content of Niacin and Thiamine. It is basically concerned in providing the characteristics substance "Glutien" which is very essential for bakery.
The common bread wheat occupies more than $90 \%$ of the total wheat area with $10 \%$ area under Triticum aestivum $L$. India is major wheat producing country in the world. It ranks second after china and at present produce more wheat than the United States of America. India occupied area under wheat 29.63 million ha with the production of 93.82 million tonnes and productivity of $35.21 \mathrm{qha}^{-1}$ grain during the year 2015-16. Uttar Pradesh with (30.20 million tonnes) production is to be the highest producer of wheat followed by Punjab (16.40 million tonnes), Madhya Pradesh (13.13 million tonnes), Haryana (11.10 million tonnes), Rajasthan (9.27 
million tonnes) etc. In Uttar Pradesh is wheat grown on 9.6 million ha with average productivity of $4693 \mathrm{~kg}$ per ha (India statistics, 2016).

Irrigation plays an important role in exploiting yield potential of high yielding wheat varieties. Advantage of optimum dose of fertilizer application is possible only under assured irrigated condition. It has been well established that dwarf wheat produce their potential yields when it is irrigated at all critical stages of plant growth viz. crown root initiation, late tillering, late jointing, flowering, milk and dough stage. In most of the wheat growing area of Uttar Pradesh, sufficient and assured irrigation water is not available for irrigation at all critical stages. It is the main reason for low productivity of wheat in the state.

\section{Materials and Methods}

The field experiment was conducted at students' instruction at farm of the C.S. Azad University of Agriculture and Technology, Kanpur. The field selected for experiment was well leveled and homogenous fertility having irrigation facility of tube well. The soil of experimental field was sandy loam in texture and neutral in $\mathrm{pH}$. The climate of Kanpur is sub-tropical, semi-arid with hot dry summer and severe cold in winter.

Maximum temperature during summer reaches up to $46^{\circ} \mathrm{C}$, while during winter it fall up to $4^{\circ} \mathrm{C}$. The mean annual precipitation of the district is about $815.6 \mathrm{~mm}$ which is mostly received in the month of July to midSeptember with occasional few showers of cyclonic rains during December and January. The total rainfall received $5.60 \mathrm{~mm}$ during crop growth period. The treatments in the experiment included scheduling of two irrigation levels and two cultivars. The experiment was evaluated in split plot design with three replications. In each treatment, nitrogen was applied $50 \%$ as basal and remaining $50 \%$ in two split as top dressing at as CRI stage and tillering stage. The required quantity of phosphorous and potassium was applied at the time of sowing in all the treatments.

Two varieties were used (i) K-1006 is a new high yielding variety of wheat developed by Chandra Shekhar Azad Agriculture University, Kanpur, suitable north eastern plain zone that including state like eastern U.P., Bihar, West Bengal, Jharkhand \& Assam. It has consistently shown high degree of resistant to yellow rust, brown rust and black rust are most common disease that are found in wheat crop. (ii) K-402 (Mahi) was released from Chandra Shekhar Azad University of Agriculture and Technology, Kanpur (U.P.). The variety is recommended for Punjab, Haryana, Rajasthan and West U.P. etc. The varietal characters possess plant height varies between $80-90 \mathrm{~cm}$, average days for maturity is $130-135$ and test weight ranges $38-40 \mathrm{gm}$. This variety also characterized as heat tolerant.

After pre - sowing irrigation, at proper moisture condition of soil, three ploughing were done with tractor drawn harrow followed by planking to achieve good tilth. The sowing of wheat seed (var. k-402, k-1006 @ $100 \mathrm{~kg} / \mathrm{ha}$ ) is done with desi plough on 28 November 2015. The spacing between row kept $20 \mathrm{~cm}$ and depth of sowing was $4-5 \mathrm{~cm}$. The irrigation was applied on physiological stages of crop growth. The irrigation depth was kept as $6 \mathrm{~cm}$ for all the irrigation treatment. The irrigation was applied at crown root initiation stage on 21 December 2015, maximum tillering stage 15 January 2016, Botting stage 10 February 2016, Milking stage 1 march 2016. Harvesting of crop was done manually with sickle at maturity on 5 April 2016. 


\section{Results and Discussion}

\section{Growth attributes}

It is evident from the data showed in table 1 that the Initial plant population of wheat crop does not show significantly difference to various scheduling of irrigation was applied to the wheat crop. Plant height of wheat at different physiological stages of crop growth was significantly influenced by different scheduling of irrigations. Application of irrigation water to wheat at Irrigation at crown root initiation $(\mathrm{CRI})+$ maximum tillering (MT) + booting (BT) + milking (MK) Stages produced significantly tallest plants at all stage of crop growth as compared to other scheduling of irrigations.

The possible reason could have been attributed that adequate supply of soil moisture to plant at its four critical stages might have increased the succulence in the meristematic cells and maintained turgor with favored better proliferation of leaf buds and plant height as compare to that under stressed conditions with irrigation given at CRI + BT + MK Stage. Similar results have been reported by Mandal et al., (2005).

Plant fresh weight of wheat at different physiological stage of crop growth was significantly influenced by different scheduling of irrigation application of irrigation water to wheat growth at CRI + MT + BT + MK Stage produced significantly highest plant weight at all the stages of crop growth as a compare to other irrigation scheduling. Dry weight of wheat at different physiological stage of crop growth was significantly influenced by different scheduling of irrigation application of irrigation water to wheat growth at CRI + MT + BT + MK Stage produced significantly highest plant weight at all the stages of crop growth as a compare to other irrigation scheduling. Greater number of irrigations and more water supply with irrigation at CRI + $\mathrm{MT}+\mathrm{BT}+\mathrm{MK}$ Stage might have stimulated the plants to have quick cell division and cell elongation of nodes and internodes results in higher fresh and dry matter production. These results are in close conformity with the findings of Mandal et al., (2006).

\section{Yield attributes}

Total no. of spikes per meter length significantly influenced by different scheduling of irrigation. Significantly higher no. of spikes per meter length of wheat was produced with four irrigation given at CRI + $\mathrm{MT}+\mathrm{BT}+\mathrm{MK}$ stage as compare to irrigation applied at three stage CRI + BT + MK. Earlier and frequent supply of irrigation water with four irrigations applied at CRI + MT + $\mathrm{BT}+\mathrm{MK}$ stage might have been responsible for better pollen maturity and fertilization, which results in greater number of spikes per meter length as comparison to three irrigation applied at CRI + BT + MK stage. The similar results have also been reported by Mubeen $e t$ al., (2013).

Grain weight per panicle of wheat was significantly influenced by different scheduling of irrigation. Significantly maximum grain weight per panicle of wheat was produced with four irrigation given at $\mathrm{CRI}+\mathrm{MT}+\mathrm{BT}+\mathrm{MK}$ stage as compare to irrigation applied at three stage CRI + BT + MK. Minimum grain weight per panicle of wheat was obtained in three irrigation applied at CRI + BT + MK stage. It might be due to the fact that timely irrigation given to wheat plant is helpful to increase grain weight of panicle in comparison to delayed irrigation. Similar observations are also reported by Youssef et al., (2013)

Various scheduling of irrigation significantly influenced test weight of wheat. Four irrigations applied at CRI + MT + BT + MK Stage produced higher test weight of wheat as 
compare to three irrigation applied at CRI + BT + MK Stage. It could be due to the fact that the plant under adequate moisture condition with four irrigations given in CRI + MT + BT + MK Stage might have produced sound and bolder seed thereby increasing the 1000-grain weight of seeds as compared to the three irrigation given at CRI + BT + MK Stage. These results are in agreement with those reported by Sharma and Ashok (2014)

Table.1 Growth, yield and economics of wheat under different irrigation levels

\begin{tabular}{|l|l|l|}
\hline Particulars & $\begin{array}{l}\text { Irrigation at CRI + BT } \\
\text { + MK Stage }\end{array}$ & $\begin{array}{l}\text { Irrigation at CRI + MT } \\
\text { + BT + MK Stage }\end{array}$ \\
\hline Growth attributes & 59.2 & 59.4 \\
\hline Plant population & 95.47 & 96.30 \\
\hline Plant height & 78.91 & 79.17 \\
\hline Fresh weight & 15.75 & 16.15 \\
\hline Dry weight & \multicolumn{2}{|l|}{} \\
\hline Yield attributes & 55.07 & 55.74 \\
\hline Total no. of spike per meter length & 2.46 & 2.72 \\
\hline Grain weight per panicle & 45.51 & 46.34 \\
\hline Test weight & 49.71 & 51.46 \\
\hline Yield & 64.18 & 73.82 \\
\hline Grain yield & 113.89 & 125.28 \\
\hline Straw yield & 43.68 & 41.07 \\
\hline Biological yield & \multicolumn{2}{|l|}{} \\
\hline Harvest index & 45,810 & 47,171 \\
\hline Economics & $1,09,148$ & $1,16,679$ \\
\hline Cost of cultivation & 63,338 & 69,508 \\
\hline Gross return & $1: 2.38$ & $1: 2.47$ \\
\hline Net return & 40 & 42 \\
\hline B:C Ratio & 553.4 & 558.4 \\
\hline Moisture studies & 8.99 & 9.22 \\
\hline Consumptive use of water & \multicolumn{2}{|l|}{} \\
\hline Total water use & \multicolumn{2}{|l|}{} \\
\hline Water use efficiency & \\
\hline
\end{tabular}

\section{Yield}

Various scheduling of irrigation significantly influenced the grain yield of wheat. Significantly higher grain yield of wheat was obtained with four irrigation applied at CRI + $\mathrm{MT}+\mathrm{BT}+\mathrm{MK}$ stages of crop growth as compared to three irrigation given at CRI $+\mathrm{BT}$ + MK stages. Various scheduling of irrigation significantly influenced the straw yield of wheat. Significantly highest straw yield of wheat was obtained with four irrigation applied at $\mathrm{CRI}+\mathrm{MT}+\mathrm{BT}+\mathrm{MK}$ stages of crop growth as compared to three irrigation given at CRI + BT + MK stages.
Various scheduling of irrigation significantly influenced the biological yield of wheat. Significantly highest biological yield of wheat was obtained with four irrigation applied at CRI $+\mathrm{MT}+\mathrm{BT}+\mathrm{MK}$ stages of crop growth as compared to three irrigation given at CRI + BT + MK stages. Application of four irrigation given at $\mathrm{CRI}+\mathrm{MT}+\mathrm{BT}+\mathrm{MK}$ stages recorded maximum harvest index of wheat, which was significantly at per that crop was irrigated four stages more than three irrigation stages.

Significant increase in number of spike per plant, length of ear per plant, number of grains per ear and higher 1000-grain weight obtained 
with four irrigation might have resulted in significantly higher grain yield. Significantly tall plants, more fresh weight per plant, dry matter accumulation per plant and higher no. of shoots were obtained with four irrigation at CRI $+\mathrm{MT}+\mathrm{BT}+\mathrm{MK}$ stages as compared to three irrigations applied at $\mathrm{CRI}+\mathrm{BT}+\mathrm{MK}$ stages might have led to the significant increase in straw yield. The increase in the grain yield with the increase in the number of irrigation was followed with the proportionate increase in dry matter production. The variation in harvest index values among the treatments was possibly thus minimized. Similar observations are also reported by Meena et al., (2015).

\section{Economics}

Four irrigation applied at $\mathrm{CRI}+\mathrm{MT}+\mathrm{BT}+$ MK stages registered maximum total cost of cultivation of wheat followed by irrigation given at three stages CRI + BT + MK of crop growth. Gross return and net return registered maximum for irrigation applied at four stages. Benefit: cost ratio of wheat produced maximum with irrigations applied at CRI + MT + BT + MK stages as compared to irrigation applied at $\mathrm{CRI}+\mathrm{MT}+\mathrm{BT}+\mathrm{MK}$ stages. The increase in gross return and net return in irrigation applied at four stages might be due to increase in grain and straw yield of wheat.

\section{Moisture studies}

The varying levels of irrigation had profound effect on consumptive use of water. Increased irrigation levels had higher consumptive water use efficiency as compared to lower irrigation levels. Total water use and water use efficiency were maximum with irrigation given at CRI + $\mathrm{MT}+\mathrm{BT}+\mathrm{MK}$ stages followed by irrigation applied at three stages CRI + BT + MK.

\section{References}

India statistics, 2016

Mandal, K.G., Hati, K.M., Misra, A.K., Bandyopadhyay, K.K. and Mohanty, M. 2005. Irrigation and Nutrient Effects on Growth and Water-Yield Relationship of Wheat (Triticum aestivum L.) in Central India. Journal of Agronomy and Crop Science191 (6): 416-425.

Mandal, K.G., Hati, K.M., Misra, A.K. and Bandyopadhyay, K.K. 2006. Assessment of irrigation and nutrient effects on growth, yield and water use efficiency of Indian mustard (Brassica juncea) in central India. Agricultural Water Management85(3):279-286.

Meena, R.K., Parihar, S.S., Singh, M. and Khanna, M. 2015. Influence of date of sowing and irrigation regimes on crop growth and yield of wheat (Triticum aestivum) and its relationship with temperature in semi-arid region. Indian Journal of Agronomy60 (1): 92-98.

Mubeen, M., Ahmad, A., Khaliq, T., Sultana, S. R., Hussain, S., Ali, A., Ali,H., and Nasim, W. 2013. Effect of Growth StageBased Irrigation Schedules on Biomass Accumulation and Resource Use Efficiency of Wheat Cultivars. AJPS4(7):1435-1442.

Sharma, K.D., and Kumar A. 2014. Identification of physiological and yield related traits of wheat (Triticum aestivum L.) under varying soil moisture stress. Journal of Agrometeorology16 (1):78-84.

Youssef, M. A., Sayed M. M. and Sadek I. 2013. Impact of Organic Manure, BioFertilizer and Irrigation Intervals on Wheat Growth and Grain Yield American-Eurasian J. Agric. \& Environ. Sci., 13 (11): 1488-1496.

\section{How to cite this article:}

Manoj Kumar Gora, M.Z. Siddiqui and Shankar Lal Choudhary. 2017. Growth Behavior of Wheat Cultivars under Different Irrigation Levels. Int.J.Curr.Microbiol.App.Sci. 6(9): 195-199. doi: https://doi.org/10.20546/ijcmas.2017.609.026 